RESEARCH PAPER RP835

Part of Journal of Research of the National Bureau of Standards, Volume 15, October 1935

\title{
INFLUENCE OF SOME SULPHUR-CONTAINING TANNING MATERIALS ON THE DETERIORATION OF VEGETABLE- TANNED LEATHERS BY SULPHURIC ACID
}

\author{
By Everett L. Wallace, Joseph R. Kanagy, and Charles L. Critchfield
}

\section{ABSTRACT}

The influence of a synthetic tanning material, sulphite cellulose, and sulphited extracts on the deterioration of leather, when used with chestnut and quebracho extracts for tanning, was studied. Leathers tanned with the aid of these materials were treated with varying amounts of sulphuric acid and aged under controlled conditions of temperature and relative humidity. Deterioration was determined by measuring the change in tensile strength after $6,12,18$, and 24 months. The amount of extractable nitrogen was also determined for the samples aged for 24 months. The results show whac deterioration as measured by tensile strength and chemical decomposition of the hide substance is a function of the $\mathrm{pH}$ value of a water extract of the sample rather than the acid content of the leather as measured by the total sulphur or the Procter and Searle method.

CONTENTS

I. Introduction

II. Materials and methods _.__ 370

III. Results and discussion

IV. Summary

\section{INTRODUCTION}

The development and increased use of materials containing sulphur in the production of vegetable-tanned leather has logically led to an investigation of the effects of these materials on the deterioration of the leather, as a function of the acidity, during storage.

Any of the direct analytical methods in use for evaluating the acidity are of doubtful value when applied to leather tanned with materials containing organic sulphur compounds.

In previous work ${ }^{1}$ at the National Bureau of Standards on the effect of acid on different leathers during storage, the deterioration has been expressed both as functions of the added sulphuric acid and of the $\mathrm{pH}$ value of an aqueous extract of the leather. It was also shown ${ }^{2}$ that the amount of added sulphuric acid which would cause serious deterioration in 2 years varied from 0.3 to 1.8 percent for the different leathers, and that the $\mathrm{pH}$ of the leather extract had a more definite relation to the loss in strength than did the acid content.

The sulphur-containing substances selected for study in this report were synthetic tanning materials, sulphited quebracho extract, and

1 BS J. Research 10, 559 (1933) RP548; J. Am. Leather Chem. Assn. 28, 125 (1933).

2 J. Research NBS 14, 121 (1935) RP761; J. Am. Leather Chem. Assn. 30, 91 (1935). 
sulphite cellulose extract. These products are commonly used in the manufacture of both heavy and light leathers.

\section{MATERIALS AND METHODS}

The leather used in this work was prepared in the experimental tannery at the National Bureau of Standards from green-salted steer hides and consisted of the following lots; lot 21 (chestnut extract and syntan); lot 22 (quebracho extract and syntan); lot 27 (sulphited quebracho extract); lot 28 (chestnut extract and syntan); lot 29 quebracho extract and syntan); lot 30 (chestnut extract and sulphite cellulose); and lot 31 (quebracho extract and sulphite cellulose). Lots 21 and 22 were tanned with a blend consisting of $25 \mathrm{lb}$ of syntan of $21^{\circ} \mathrm{Be}$ to $75 \mathrm{lb}$ of the liquid vegetable extracts containing 25 percent of tannin. This is a larger proportion of syntan than is normally used in the production of heavy leather, but was used to assure a high Procter and Searle value. Lot 27 was tanned with sulphited quebracho extract and the $\mathrm{pH}$ of the liquors was maintained at approximately 4 by the use of acetic acid. Lots 28 and 29 were tanned with a blend similar to that used for lots 21 and 22 , except that the proportion was $10 \mathrm{lb}$ of syntan to $90 \mathrm{lb}$ of liquid vegetable extract. Lot 30 was tanned with a blend consisting of 75 percent of chestnut extract and 25 percent of sulphite-cellulose extract. Lot 31 was similar to lot 30 , except that quebracho was used instead of the chestnut extract. The chemical analyses of these leathers before aging are given in table 1 .

\section{Table 1.-Chemical Analyses of Leather}

[Results expressed in percentage, excepting for degree of tannage and $\mathrm{pH}$ value]

\begin{tabular}{|c|c|c|c|c|c|c|c|}
\hline \multirow[b]{2}{*}{ Items determined } & \multicolumn{7}{|c|}{ Leather lot number and tanning material } \\
\hline & $\begin{array}{l}21- \\
\text { Chestnut } \\
\text { syntan }\end{array}$ & $\begin{array}{l}22-\text { Que- } \\
\text { bracho } \\
\text { syntan }\end{array}$ & $\begin{array}{c}27 \text {-Que- } \\
\text { bracho } \\
\text { sul- } \\
\text { phited }\end{array}$ & $\begin{array}{l}28- \\
\text { Chestnut } \\
\text { syntan }\end{array}$ & $\begin{array}{l}29-\text {-Que- } \\
\text { bracho } \\
\text { syntan }\end{array}$ & $\begin{array}{l}30- \\
\text { Chestnut } \\
\text { sulphite } \\
\text { cellulose }\end{array}$ & $\begin{array}{l}\text { 31-Que- } \\
\text { bracho } \\
\text { sulphite } \\
\text { cellulose }\end{array}$ \\
\hline $\begin{array}{l}\text { Water-soluble } \\
\text { Hide substance }\end{array}$ & $\begin{array}{r}9.19 \\
49.68\end{array}$ & $\begin{array}{r}8.93 \\
47.93\end{array}$ & $\begin{array}{r}8.28 \\
48.95\end{array}$ & $\begin{array}{r}8.40 \\
48.16\end{array}$ & $\begin{array}{l}11.53 \\
45.69\end{array}$ & $\begin{array}{l}\text { 10. } 26 \\
47.22\end{array}$ & $\begin{array}{l}11.04 \\
45.06\end{array}$ \\
\hline Grease (petroleum-ether ex- & & & & & & & \\
\hline tract) & 3. 23 & 3. 89 & 4. 37 & 3. 69 & 4. 73 & 4. 26 & 2.92 \\
\hline $\begin{array}{l}\text { Insoluble ash } \\
\text { In }\end{array}$ & $\begin{array}{r}11.96 \\
.20\end{array}$ & 9. 97 & 9. 40 & 11. 26 & 9. 91 & $\begin{array}{r}10.86 \\
12\end{array}$ & $\begin{array}{r}9.80 \\
10\end{array}$ \\
\hline Combined tannin ${ }^{1}$ & 25.74 & 29.07 & 28.90 & 28.38 & 28.06 & 27.28 & 31.08 \\
\hline Total_. & 100.00 & 100.00 & 100.00 & 100.00 & 100.00 & 100.00 & 100.00 \\
\hline Degree of tannage ${ }^{2}$ & 52.00 & 61.00 & 59.00 & & & 58.00 & 69.00 \\
\hline Soluble tans. & 7.87 & 7. 73 & 6. 61 & $\begin{array}{r}7.10 \\
7.10\end{array}$ & 9.91 & 8.76 & $\begin{array}{r}9.00 \\
9.56\end{array}$ \\
\hline Soluble nontans. & 1.32 & 1. 20 & 1.57 & 1.30 & 1. 62 & 1.50 & 1. 48 \\
\hline Total ash & $\begin{array}{r}1.34 \\
.34\end{array}$ & .42 & .18 & .31 & .16 & .31 & .27 \\
\hline Acid (Procter and Searle) & 1.70 & 1. 61 & .80 & .35 & .41 & .62 & .70 \\
\hline pH value ${ }^{3}$ & 3.62 & 4. 36 & 3.90 & 4.07 & 4. 58 & 3.72 & 4. 04 \\
\hline
\end{tabular}

${ }^{1}$ Determined by difference.

2 Ratio of combined tannin to hide substance.

$35 \mathrm{~g}$ of leather in $100 \mathrm{ml}$ of distilled water.

The different lots of leather were divided into 4 groups for acid treatment and aging. The original tensile strength of the leather was determined by the average of 2 specimens cut from each block. The leather was then treated with acid, air dried, and after conditioning at 65-percent relative humidity, and tensile strengths of 
2 more specimens from each block were measured to determine the immediate effect of the treatment. The blocks containing no added acid, used for determining the normal aging of the leather, were treated with water. The method of sampling was similar to that described by Bowker, Wallace, and Kanagy in their report on the influence of magnesium sulphate on the deterioration of vegetabletanned leather by sulphuric acid. ${ }^{3}$

The original $\mathrm{pH}$ values and sulphuric-acid content of the different lots of leathers are given in table 2 .

TABLE 2.-Original $\mathrm{pH}$ Values and Sulphuric-Acid Content of the Leathers

\begin{tabular}{|c|c|c|c|c|c|c|c|c|}
\hline \multirow{4}{*}{$\begin{array}{l}\text { Leather lot number and } \\
\text { tanning material }\end{array}$} & \multirow{4}{*}{$\begin{array}{l}\text { Sam- } \\
\text { ple } \\
\text { num- } \\
\text { ber }\end{array}$} & \multirow{4}{*}{$\begin{array}{c}\text { Origi- } \\
\text { nal } \\
\text { pH }\end{array}$} & \multicolumn{6}{|c|}{ Percentage of sulphuric acid in dry leather } \\
\hline & & & \multicolumn{6}{|c|}{ Method } \\
\hline & & & \multicolumn{2}{|c|}{$\begin{array}{l}\text { Procter and } \\
\text { Searle }\end{array}$} & \multicolumn{2}{|c|}{ Oxygen bomb } & \multicolumn{2}{|c|}{$\begin{array}{l}\text { Nitric acid } \\
\text { bromine }\end{array}$} \\
\hline & & & Total & Added & Total 1 & Added ${ }^{2}$ & Total 1 & Added 2 \\
\hline 21-Chestnut syntan... & $\begin{array}{l}0 \\
1 \\
2 \\
3\end{array}$ & $\begin{array}{l}3.62 \\
2.64 \\
2.18 \\
1.94\end{array}$ & $\begin{array}{l}\text { 1. } 70 \\
2.30 \\
3.20 \\
4.20\end{array}$ & $\begin{array}{l}0.00 \\
0.60 \\
1.50 \\
2.50\end{array}$ & - & & $\begin{array}{l}0.72 \\
1.68 \\
2.48 \\
3.50\end{array}$ & $\begin{array}{l}0.00 \\
0.96 \\
1.76 \\
2.78\end{array}$ \\
\hline 22-Quebracho syntan... & $\begin{array}{l}0 \\
1 \\
2 \\
3\end{array}$ & $\begin{array}{l}4.36 \\
2.94 \\
2.28 \\
1.98\end{array}$ & $\begin{array}{l}\text { 1. } 61 \\
\text { 2. } 21 \\
\text { 3. } 28 \\
\text { 4. } 11\end{array}$ & $\begin{array}{l}0.00 \\
0.60 \\
1.67 \\
2.50\end{array}$ & 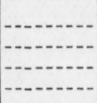 & 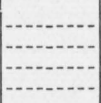 & $\begin{array}{l}0.65 \\
1.49 \\
2.57 \\
3.44\end{array}$ & $\begin{array}{l}0.00 \\
0.84 \\
1.92 \\
2.79\end{array}$ \\
\hline 27-Sulphited quebracho_. & $\begin{array}{l}0 \\
1 \\
2 \\
3\end{array}$ & $\begin{array}{l}3.90 \\
2.76 \\
2.35 \\
2.15\end{array}$ & $\begin{array}{l}0.80 \\
\text { 1. } 59 \\
\text { 2. } 34 \\
\text { 3. } 06\end{array}$ & $\begin{array}{l}0.00 \\
0.79 \\
1.54 \\
2.26\end{array}$ & $\begin{array}{l}2.30 \\
3.10 \\
3.86 \\
4.62\end{array}$ & $\begin{array}{l}0.00 \\
0.80 \\
1.56 \\
2.32\end{array}$ & $\begin{array}{l}1.65 \\
2.54 \\
3.18 \\
3.94\end{array}$ & $\begin{array}{l}0.00 \\
0.89 \\
1.53 \\
2.29\end{array}$ \\
\hline 28-Chestnut syntan... & $\begin{array}{l}0 \\
1 \\
2 \\
3\end{array}$ & $\begin{array}{l}4.07 \\
3.01 \\
2.65 \\
2.38\end{array}$ & $\begin{array}{l}0.35 \\
\text { 1. } 08 \\
\text { 1. } 74 \\
\text { 2. } 40\end{array}$ & $\begin{array}{l}0.00 \\
0.73 \\
1.39 \\
2.05\end{array}$ & $\begin{array}{l}1.02 \\
1.82 \\
2.60 \\
3.50\end{array}$ & $\begin{array}{l}0.00 \\
0.80 \\
1.58 \\
2.48\end{array}$ & $\begin{array}{l}0.10 \\
0.88 \\
1.62 \\
2.48\end{array}$ & $\begin{array}{l}0.00 \\
0.78 \\
1.52 \\
2.38\end{array}$ \\
\hline 29-Quebracho syntan... & $\begin{array}{l}0 \\
1 \\
2 \\
3\end{array}$ & $\begin{array}{l}4.58 \\
3.13 \\
2.64 \\
2.40\end{array}$ & $\begin{array}{l}0.41 \\
0.96 \\
1.77 \\
2.25\end{array}$ & $\begin{array}{l}0.00 \\
0.55 \\
1.36 \\
1.84\end{array}$ & $\begin{array}{l}0.89 \\
1.66 \\
2.45 \\
3.07\end{array}$ & $\begin{array}{l}0.00 \\
0.77 \\
1.56 \\
2.18\end{array}$ & $\begin{array}{l}0.28 \\
1.03 \\
1.83 \\
2.47\end{array}$ & $\begin{array}{l}0.00 \\
0.75 \\
1.57 \\
2.19\end{array}$ \\
\hline 30 - Chestnut sulphite cellulose & $\begin{array}{l}0 \\
1 \\
2 \\
3\end{array}$ & $\begin{array}{l}3.72 \\
2.67 \\
2.33 \\
2.03\end{array}$ & $\begin{array}{l}0.62 \\
1.20 \\
1.88 \\
2.80\end{array}$ & $\begin{array}{l}0.00 \\
0.58 \\
1.26 \\
2.18\end{array}$ & $\begin{array}{l}2.44 \\
3.16 \\
3.94 \\
4.59\end{array}$ & $\begin{array}{l}0.00 \\
0.72 \\
1.50 \\
2.15\end{array}$ & $\begin{array}{l}1.74 \\
2.35 \\
3.12 \\
3.68\end{array}$ & $\begin{array}{l}0.00 \\
0.61 \\
1.38 \\
1.94\end{array}$ \\
\hline 31-Quebracho sulphite cellulose & $\begin{array}{l}0 \\
1 \\
2 \\
3\end{array}$ & $\begin{array}{l}4.04 \\
2.89 \\
2.33 \\
2.04\end{array}$ & $\begin{array}{l}0.70 \\
\text { 1. } 23 \\
\text { 2. } 27 \\
2.80\end{array}$ & $\begin{array}{l}0.00 \\
0.53 \\
1.57 \\
2.10\end{array}$ & $\begin{array}{l}\text { 2. } 48 \\
\text { 3. } 19 \\
3.90 \\
4.68\end{array}$ & $\begin{array}{l}0.00 \\
0.71 \\
1.42 \\
2.20\end{array}$ & $\begin{array}{l}1.57 \\
2.35 \\
3.13 \\
3.87\end{array}$ & $\begin{array}{l}0.00 \\
0.78 \\
1.56 \\
\text { 2. } 30\end{array}$ \\
\hline
\end{tabular}

1 Sulphuric acid calculated from the total sulphur in the sample.

2 Sulphurit acid added, calculated from the difference in acid content of the sample before and after treatment.

The amount of acid added was determined by the difference between the calculated amount of acid in the original sample and in the sample after treatment. The acid was determined by the following methods: Modified Procter and Searle; complete combustion of the sample in an oxygen bomb and a subsequent gravimetric determination of the sulphates in the bomb washings; and by oxidation of the sample with nitric acid and a gravimetric determination of the sulphates formed.

\footnotetext{
${ }^{3}$ J. Research NBS 14, 121 (1935) RP761; J. Am. Leather Chem. Assn. 30, 91 ${ }_{4}(1935)$. $16373-35-3$
} 
It is shown in table 2 that the agreement between the bomb and the nitric-acid methods is close for the calculated amount of acid added to the samples, but that the acid calculated from the total sulphur in the sample before treatment is much higher by the bomb method. This indicates that certain sulphur compounds in these leathers are resistant to oxidation by the nitric-acid treatment.

\section{RESULTS AND DISCUSSION}

The results for the tensile strength determinations for the different leathers and aging periods are given in table 3.

TABLE 3.- Results of tensile strength determinations of leathers aged at $70^{\circ} \mathrm{F}$, calculated in pounds per square inch

Lot 21 Aged at 65-Percent Relative Humidity

\begin{tabular}{|c|c|c|c|c|c|c|}
\hline \multirow{2}{*}{ Sample number } & \multirow{2}{*}{$\begin{array}{c}\text { Un- } \\
\text { treated }\end{array}$} & \multicolumn{5}{|c|}{ Age of treated samples in months } \\
\hline & & 0 & 6 & 12 & 18 & 24 \\
\hline 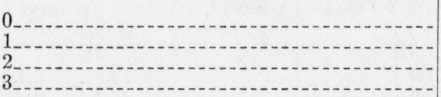 & $\begin{array}{l}3872 \\
4218 \\
4058 \\
4270\end{array}$ & $\begin{array}{r}3739 \\
3572 \\
3273 \\
3111\end{array}$ & $\begin{array}{l}3615 \\
3378 \\
2964 \\
2101\end{array}$ & $\begin{array}{l}3550 \\
3546 \\
2848 \\
1516\end{array}$ & $\begin{array}{l}3556 \\
3172 \\
2616 \\
1221\end{array}$ & $\begin{array}{l}3522 \\
3270 \\
2295 \\
1271\end{array}$ \\
\hline
\end{tabular}

Lot 21 Aged at 85-Percent Relative Humidity

\begin{tabular}{r|r|r|r|r|r|r}
\hline 0 & 3670 & a 3769 & 3322 & 3422 & 3232 \\
2838 & 2531 \\
1528 & 2390 \\
1363 \\
315
\end{tabular}

Lot 22 Aged at 65-Percent Relative Humidity

\begin{tabular}{|c|c|c|c|c|c|c|}
\hline${ }^{0}{ }_{1}{ }^{2}$ & $\begin{array}{l}4718 \\
4850 \\
4791 \\
5146\end{array}$ & $\begin{array}{r}4560 \\
4748 \\
4202 \\
4293\end{array}$ & $\begin{array}{l}4698 \\
4491 \\
4078 \\
3841\end{array}$ & $\begin{array}{l}4588 \\
4476 \\
4366 \\
3162\end{array}$ & $\begin{array}{l}4233 \\
4438 \\
3990 \\
2796\end{array}$ & $\begin{array}{l}4652 \\
4688 \\
4217 \\
3560\end{array}$ \\
\hline
\end{tabular}

Lot 22 Aged at 85-Percent Relative Humidity

\begin{tabular}{|c|c|c|c|c|c|c|}
\hline 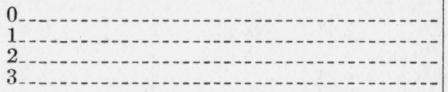 & $\begin{array}{l}4848 \\
4659 \\
5014 \\
4738\end{array}$ & $\begin{array}{r}4837 \\
4612 \\
4762 \\
4095\end{array}$ & $\begin{array}{l}4445 \\
4192 \\
4264 \\
3065\end{array}$ & $\begin{array}{l}4692 \\
4006 \\
3695 \\
1877\end{array}$ & $\begin{array}{l}4323 \\
3835 \\
3642 \\
1500\end{array}$ & $\begin{array}{l}4520 \\
4170 \\
3387 \\
1457\end{array}$ \\
\hline
\end{tabular}

Lot 27 Aged at 65-Percent Relative Humidity

\begin{tabular}{|c|c|c|c|c|c|c|}
\hline $\begin{array}{l}0_{1} \\
0_{1}-2-1\end{array}$ & $\begin{array}{l}3467 \\
3130 \\
3430 \\
3512\end{array}$ & $\begin{array}{r}3637 \\
3381 \\
3424 \\
3162\end{array}$ & $\begin{array}{l}3325 \\
3209 \\
3138 \\
2513\end{array}$ & $\begin{array}{l}3469 \\
3280 \\
3162 \\
2370\end{array}$ & $\begin{array}{l}3310 \\
3060 \\
2915 \\
2169\end{array}$ & $\begin{array}{l}3700 \\
3410 \\
3211 \\
2078\end{array}$ \\
\hline
\end{tabular}

Lot 28 Aged at 65-Percent Relative Humidity

\begin{tabular}{|c|c|c|c|c|c|c|}
\hline 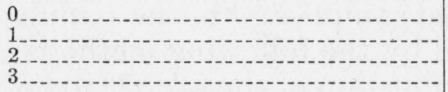 & $\begin{array}{l}3446 \\
3415 \\
3270 \\
3315\end{array}$ & $\begin{array}{r}3458 \\
3246 \\
3029 \\
2982\end{array}$ & $\begin{array}{l}3359 \\
2851 \\
2640 \\
2240\end{array}$ & $\begin{array}{l}3498 \\
2973 \\
2330 \\
1862\end{array}$ & $\begin{array}{l}3002 \\
2762 \\
2010 \\
1465\end{array}$ & $\begin{array}{l}3410 \\
2826 \\
2072 \\
1500\end{array}$ \\
\hline
\end{tabular}

Lot 29 Aged at 65-Percent Relative Humidity

\begin{tabular}{|c|c|c|c|c|c|c|}
\hline $\begin{array}{l}0 \\
0 \\
1\end{array}$ & $\begin{array}{l}3795 \\
3797 \\
3961 \\
3822\end{array}$ & $\begin{array}{r}4090 \\
3850 \\
3706 \\
3545\end{array}$ & $\begin{array}{l}3970 \\
3622 \\
3610 \\
3285\end{array}$ & $\begin{array}{l}4102 \\
3890 \\
3532 \\
3290\end{array}$ & $\begin{array}{l}3661 \\
3670 \\
3437 \\
3113\end{array}$ & $\begin{array}{l}3940 \\
3768 \\
3430 \\
3002\end{array}$ \\
\hline
\end{tabular}


TABLE 3.-Results of tensile strength determinations of leathers aged at $70^{\circ} \mathrm{F}$, calculated in pounds per square inch-Continued

Lot 30 Aged at 65-Percent Relative Humidity

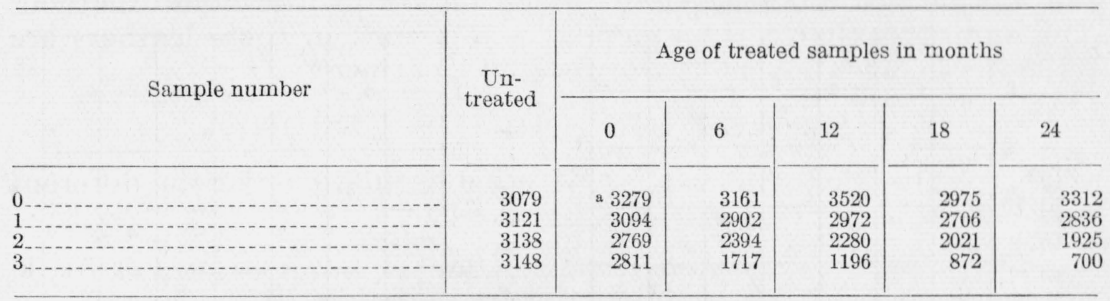

Lot 31 Aged at 65-Percent Relative Humidity

\begin{tabular}{r|r|r|r|r|r|r}
\hline 0 & 3071 & a 3250 & 3360 & 3389 & 3338 \\
3290 & 3360 \\
1 & 3010 & 3082 & 2920 & 3198 & 3225 \\
2 & 3450 & 3170 & 3166 & 3112 & 3020 \\
2240 & 3138 & 2689 & 2360 & 2190 \\
\hline
\end{tabular}

a Treated with water for control.

Lots 21 and 22 were aged at $70^{\circ} \mathrm{F}$ and at 65 - and 85 -percent relative humidities. The remaining lots were aged at $70^{\circ} \mathrm{F}$ and 65 -percent relative humidity.

The normal aging for the leathers containing no added acid is shown for the different leathers and aging periods in table 3 . The average loss in tensile strength for lot 21 , chestnut-syntan leather, containing: no added acid is, for the 2 -year aging period, approximately 9 percent. The average loss in tensile strength for a 2 -year aging period of 3 lots of straight chesnut-tanned leather previously reported, ${ }^{4}{ }^{5}{ }^{6}$ was approximately 9 percent. This indicates that the large percentage of syntan used in the tanning liquors and the resulting high Procter and Searle value of 1.70 percent had no appreciable influence on the loss in tensile strength of the leather containing no added acid over an aging period of 2 years. The chestnut-syntan leather in lot 28 , containing no added acid, showed less than a normal deterioration in strength, and the chestnut-sulphite cellulose leathers in lot 30 were stronger at the end of the 2-year period. The quebracho leathers containing syntan and sulphite cellulose and the sulphited quebracho leathers appear to have aged normally when compared with previous lots of these leathers tanned without the use of sulphur-containing materials. As shown in table 3 , in all cases there was a loss in tensile strength immediately after treatment of the samples with acid when compared with the samples treated with water for control. This loss in strength is considered in the final results as a part of the total deterioration.

The results for the deterioration of the leathers for the 2-year aging period as a function of the original $\mathrm{pH}$ are given in figures 1 to 3 , inclusive. The percentage change in tensile strength has been corrected for the loss in strength of the control samples containing no added acid, so that the points in the graphs represent the deterioration caused by the acid.

\footnotetext{
4 J. Am. Leather Chem. Assn. 29, 623 (1934).

$\checkmark \mathrm{J}$. Am. Leather Chem. Assn. 30, 91 (1935).

6 J. Research NBS 15,73 (1935) RP811.
} 
Figure 1 shows the effect of humidity on the deterioration of these samples during storage. The leather stored at 85 -percent relative humidity showed a larger percentage loss in tensile strength than
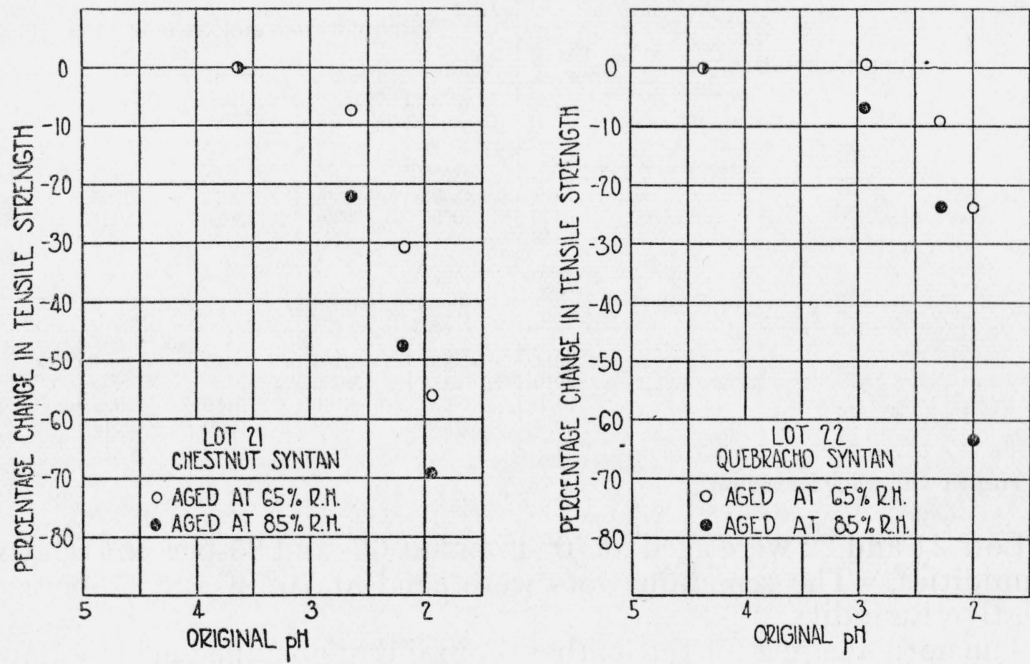

FIGURE 1.-Effect of $\mathrm{pH}$ on the change in tensile strength of leathers aged for 2 years.

similar leathers stored at 65-percent relative humidity. This is particularly noticeable with the leathers having a low $\mathrm{pH}$ value.
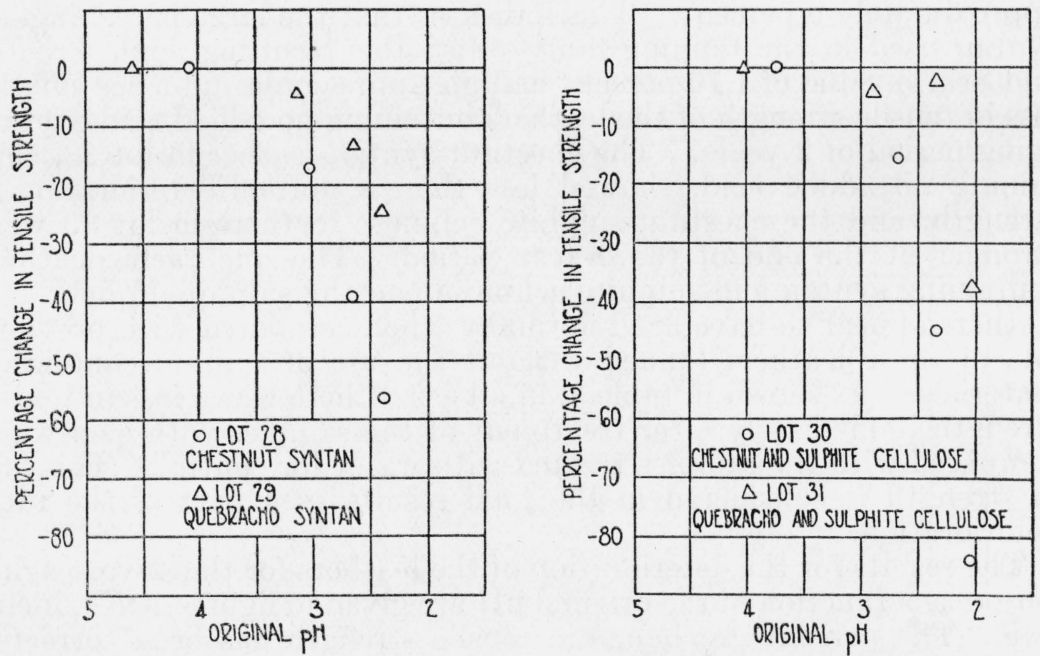

FIGURE 2.-Effect of $\mathrm{pH}$ on the change in tensile strength of leathers aged for 2 years.

The chestnut leathers at the lower $\mathrm{pH}$ values show a much greater deterioration than the quebracho leathers at the same $\mathrm{pH}$.

In figure 2 , lot 31 , the point representing the percentage loss in tensile strength for the quebracho leather having a $\mathrm{pH}$ value of 2.3 is 
doubtiul, probably because of a variation in the uniformity of this group of samples, since it is shown in table 2 that there was a much greater loss in strength for the 18 -month period than for the 24 -month period.

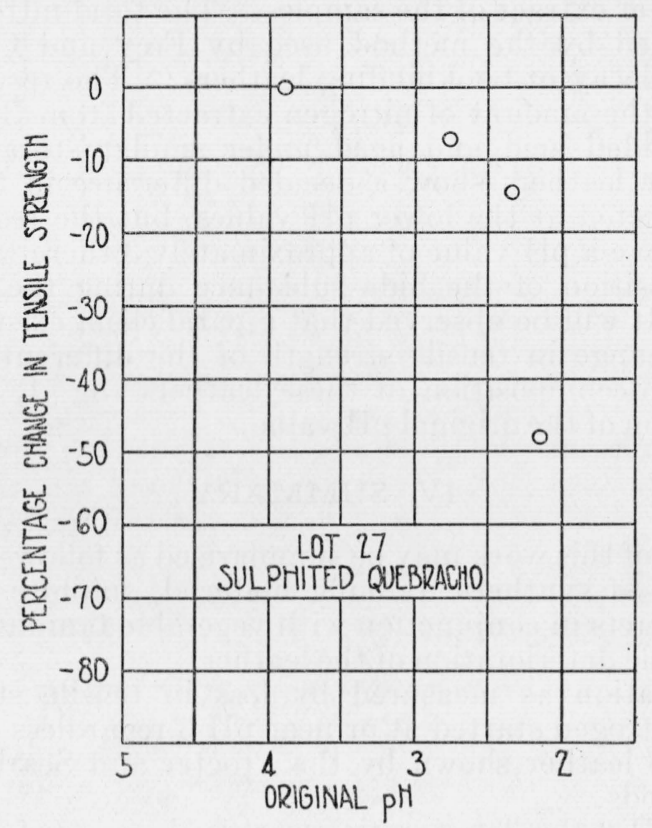

FIGURE 3.-Effect of $\mathrm{pH}$ on the change in tensile strength of leather aged for 2 years.

The results for the 7 lots of leather are shown plotted on the same graph in figure 4 . With the exception of 1 lot of leather, the percent-

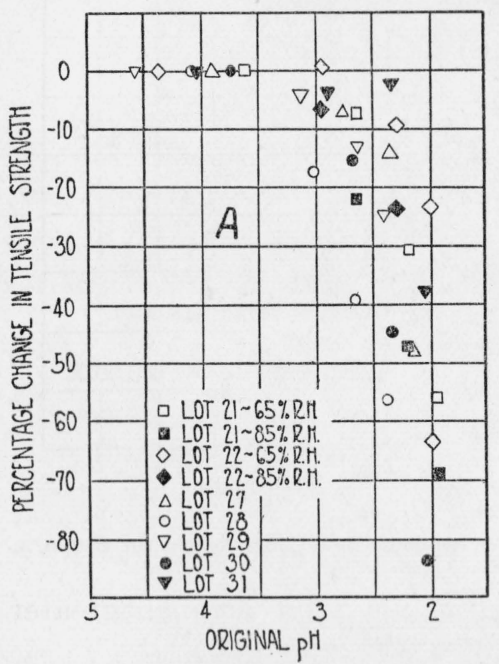

Graph A.-Effect of $\mathrm{pH}$ on the :hange in tensile strength.

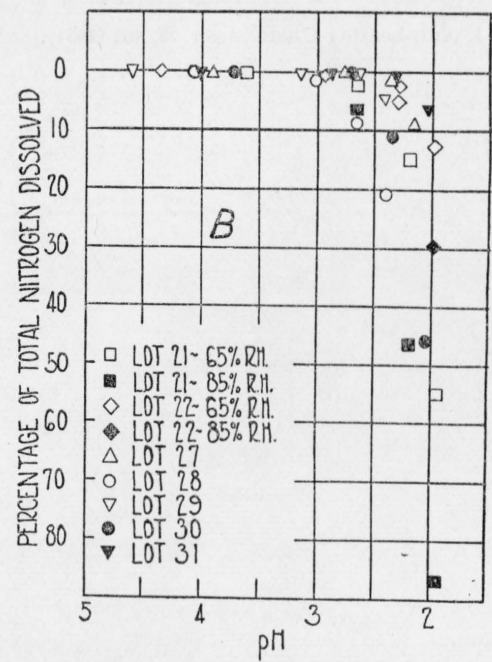

Graph B.-Efiect of $\mathrm{pH}$ on the total nitrogen dissolved.

FIGURE 4.-Results for the $\%$ lots of leather showing physical and chemical deterioration after 2-year aging period, as a function of the original $\mathrm{pH}$. 
age change in tensile strength of the samples having an original $\mathrm{pH}$ of 3 or higher, was less than 10 over the 2 -year aging period.

The chemical change in the leather, shown by the amount of soluble nitrogen, is also presented in figure 4 as a function of the $\mathrm{pH}$ value of a water extract of the samples. The total nitrogen extracted was determined by the method used by Frey and Clarke in their work on the decay of bookbinding leathers. ${ }^{7}$ The results have been corrected for the amount of nitrogen extracted from the leather containing no added acid and aged under similar storage conditions. Some of these leathers show a decided difference in the amount of nitrogen extracted at the lower $\mathrm{pH}$ values, but the results definitely show that above a $\mathrm{pH}$ value of approximately 3 there was no appreciable decomposition of the hide substance during the 2-year period of the test. It will be observed that a parallelism exists between the percentage change in tensile strength of the different leathers, and the chemical decomposition of these leathers (fig. 4, graphs A and B) as a function of the original $\mathrm{pH}$ value.

\section{SUMMARY}

The results of this work may be summarized as follows:

1. The use of synthetic tanning material, sulphite cellulose, and sulphited extracts in conjunction with vegetable tannins did not cause any appreciable deterioration of the leather.

2. Deterioration as measured by loss in tensile strength or by extractable nitrogen started at or near $\mathrm{pH} 3$ regardless of the amount of acid in the leather shown by the Procter and Searle or the total sulphur methods.

3 . Below $\mathrm{pH} 3$ the deterioration was much greater for leathers containing chestnut extract than for leathers containing quebracho extract.

Washington, August 6, 1935.

7 J. Am. Leather Chem. Assn. 26, 461 (1931). 